\title{
ANALYSIS OF EQUINE FEEDING SYSTEMS IN SELECTED EQUESTRIAN CENTERS AND STABLES
}

\section{ANALIZA SYSTEMU ŻYWIENIA KONI W WYBRANYCH OŚRODKACH JEŹDZIECKICH I STAJNIACH}

Department of Animal Nutrition and Feed Management, Siedlce University of Natural Sciences and Humanities, Poland

\begin{abstract}
Streszczenie. Celem pracy była analiza wiedzy i świadomości posiadaczy koni w Polsce w zakresie żywienia i profilaktyki prozdrowotnej układu pokarmowego tych zwierząt oraz przegląd stosowanych pasz. Znajomość budowy, funkcjonowania układu pokarmowego i przebiegu trawienia jest niezbędna do prawidłowego zaplanowania żywienia szczególnie w przypadku koni sportowych. Posiadanie gruntownej wiedzy z zakresu żywienia tych zwierząt pozwoli uniknąć problemów z kondycją konia i zmniejszy ryzyko schorzeń przewodu pokarmowego. Konie są zwierzętami, którym pokrycie podstawowych potrzeb bytowych zapewnia pastwisko. Jednakże praca dla człowieka, która wiąże się ze zwiększeniem aktywności fizycznej zwierzęcia, wymaga dostarczenia mu dodatkowych źródeł energii i pozostałych składników pokarmowych. $\mathrm{Na}$ największe trudności natrafiamy w przypadku żywienia koni wyczynowych, które są związane z prawidłowym określeniem zapotrzebowania energetycznego, dostosowanego do stopnia wytrenowania i obciążenia treningowego, a także z doborem dodatków mineralno-witaminowych pokrywających potrzeby zwierząt. Cały system żywienia jest bardzo ważny, ponieważ jest wiodącym czynnikiem wpływającym na stan zdrowia każdego organizmu.
\end{abstract}

Key words: nutrition, feed, horse-riding facilities, stables, horses.

Słowa kluczowe: żywienie, pasze, ośrodki jeździeckie, stajnie, konie.

\section{INTRODUCTION}

Horses in Poland are mainly used for recreational riding and equestrian sports. Riding schools are becoming more and more popular, especially among children and young people. Apart from horse riding itself, the instruction extends to methods of communicating with the horse, basic care procedures, and first aid in case of emergency. Proper equine nutrition is seldom dealt with in riding schools, though. In consequence, young, skilled horse-riders are not really prepared to evaluate the nutritional requirements and feed quality, or the condition of the horse. Yet it is very important, since those young enthusiasts of equestrianism are likely to become horse owners and caregivers in the future. If we analyze the way the horses are fed, we can learn interesting facts on the nutritional expertise and awareness of the owners of horses in Poland.

Corresponding author - Adres do korespondencji: Alina Janocha, Department of Animal Nutrition and Feed Management, Siedlce University of Natural Sciences and Humanities, Bolesława Prusa 14, 08-110 Siedlce, Poland, e-mail: alina.janocha@uph.edu.pl 
Horses belong to those herbivorous animals that may satisfy their nutritional requirements by simply grazing on a meadow. However, working for man is inevitably associated with increased activity of the horse, which requires additional energy and nutrients (Pięta 2004, 2009). The most difficult is to design the nutrition of performance horses, which is related with accurate evaluation of energy needs at the given level of training effort, as well as with providing appropriate mineral-vitamin supplementation that will meet the needs of the horse (Chachułowa 2001). Calculating a racing horse's daily ration, one needs to consider the horse's requirements for nutrients. The basic criteria are the type of the horse, age, body weight, sex and physiological status, condition, digestive system specificity and the kind of work performed. Also important are other factors, such as the fitness level, the effort related to the arena surface condition and the disposition of the horse. Hence, the daily ration for performance horses should be calculated individually for each animal, monitored regularly and possibly modified if needed (Pięta 2004, 2009; Kowalska 2008a,b).

Equine requirements for energy, protein and minerals grow with an increase in the intensity of exercise performed by the horse. Tables 1 and 2 below illustrate, how big these changes might be.

Table 1. Daily nutritional requirements of a horse weighing $500 \mathrm{~kg}$, performing work of medium intensity (ambitious recreation)

Tabela 1. Dzienne zapotrzebowanie żywieniowe konia, o masie $500 \mathrm{~kg}$, wykonującego pracę o średniej intensywności (ambitna rekreacja)

\begin{tabular}{|c|c|c|c|c|c|c|c|c|c|c|c|c|c|}
\hline $\begin{array}{l}E S^{*} \\
{[\mathrm{MJ}]}\end{array}$ & $\begin{array}{c}\text { BOS* }^{*} \\
{[\mathrm{~g}]}\end{array}$ & $\begin{array}{l}\mathrm{Ca} \\
{[\mathrm{g}]}\end{array}$ & $\begin{array}{c}P \\
{[g]}\end{array}$ & $\begin{array}{l}\mathrm{Mg} \\
{[\mathrm{g}]}\end{array}$ & $\begin{array}{c}\text { K } \\
{[\mathrm{g}]}\end{array}$ & $\begin{array}{l}\mathrm{Na} \\
{[\mathrm{g}]}\end{array}$ & $\begin{array}{c}\mathrm{Cl} \\
{[\mathrm{g}]}\end{array}$ & $\begin{array}{c}S \\
{[g]}\end{array}$ & $\begin{array}{c}\text { Co } \\
{[\mu g]}\end{array}$ & $\begin{array}{c}\mathrm{Cu} \\
{[\mathrm{mg}]}\end{array}$ & $\begin{array}{c}\mathrm{Fe} \\
{[\mathrm{mg}]}\end{array}$ & $\begin{array}{c}\mathrm{Mn} \\
{[\mathrm{mg}]}\end{array}$ & $\underset{[\mathrm{mg}]}{\mathrm{Zn}}$ \\
\hline 96 & 480 & 35 & 21 & 11.5 & 32 & 17.8 & 53.3 & 16.9 & 600 & 112 & 450 & 450 & 450 \\
\hline
\end{tabular}

ES - digestible energy - energia strawna, BOS - digestible crude protein - białko ogólne strawne.

${ }^{*}$ Requirement level - Wartość zapotrzebowania (Meyer, Coenen 2009).

Source: based on Nutrient Requirements of Horses (2007).

Źródło: na podstawie Nutrient Requirements of Horses (2007).

Table 2. Daily nutritional requirements of a horse weighing $500 \mathrm{~kg}$, performing work of high intensity (sport training)

Tabela 2. Dzienne zapotrzebowanie żywieniowe konia, o masie $500 \mathrm{~kg}$, wykonującego ciężką pracę (trening sportowy)

\begin{tabular}{|c|c|c|c|c|c|c|c|c|c|c|c|c|c|}
\hline $\begin{array}{l}E S^{*} \\
{[\mathrm{MJ}]}\end{array}$ & $\begin{array}{c}\mathrm{BOS}^{*} \\
{[\mathrm{~g}]}\end{array}$ & $\begin{array}{l}\mathrm{Ca} \\
{[\mathrm{g}]}\end{array}$ & $\begin{array}{l}\mathrm{P} \\
{[\mathrm{g}]}\end{array}$ & $\begin{array}{l}\mathrm{Mg} \\
{[\mathrm{g}]}\end{array}$ & $\begin{array}{c}\mathrm{K} \\
\text { [g] }\end{array}$ & $\begin{array}{l}\mathrm{Na} \\
{[\mathrm{g}]}\end{array}$ & $\begin{array}{l}\mathrm{Cl} \\
{[\mathrm{g}]}\end{array}$ & $\begin{array}{c}S \\
{[g]}\end{array}$ & $\begin{array}{c}\text { Co } \\
{[\mu \mathrm{g}]}\end{array}$ & $\begin{array}{c}\mathrm{Cu} \\
{[\mathrm{mg}]}\end{array}$ & $\begin{array}{c}\mathrm{Fe} \\
{[\mathrm{mg}]}\end{array}$ & $\begin{array}{c}\mathrm{Mn} \\
{[\mathrm{mg}]}\end{array}$ & $\begin{array}{c}\mathrm{Zn} \\
{[\mathrm{mg}]}\end{array}$ \\
\hline 125 & 630 & 40 & 29 & 15 & 39 & 25.5 & 66.5 & 18.8 & 600 & 125 & 500 & 500 & 500 \\
\hline
\end{tabular}

Explanantions see Table 1 - Objaśnienia zob. tab. 1.

Source: based on Nutrient Requirements of Horses (2007).

Źródło: na podstawie Nutrient Requirements of Horses (2007). 
Water represents the largest part of the cell, tissue and the whole living system, and is therefore the most significant nutrient. In the horse's body, water is stored in the intravascular (blood vessels), intracellular and extracellular space. Additionally, equine-specific water storage is the cecum and the colon (Pilliner 2008). A horse's water needs estimation must include ambient temperature, humidity, body weight, type and intensity of exercise, as well as the kind of feed. The demand for water of the horse in training will be at a level of 50 liters per day. However, this is not a fixed value, it will change depending on the air temperature, perspiration and intensity of training. Most preferably, horses should always have unlimited access to clean and fresh water, irrespective of temperature or season. Water intake should be restricted only during the time following intensive exercise, before the body returns to its normal state. The extraordinary adaptability which allows horses to live in extremely varied climatic conditions results not only from intensive mental activity, but also from the high activity of the skin. No other species, like the human and the horse, has such an active skin, in which sweat glands are found on the entire surface of the body covering (Blendinger 1980; Szarska 2003; Meyer and Coenen 2009).

The most important principle in equine feeding management is frequent feeding of small quantities. The specific structure and small size of equine stomach makes it vulnerable to overloading and, possibly, colic. After an intake of large amounts of concentrate, an increase in glucose level is observed, which stimulates the pancreas to produce insulin. As a result, insulin transports excess glucose into the muscles, liver and other tissues, where it is stored as glycogen. By feeding the horse before planned effort we want to mobilize the release of glucose rather than store it. If feed doses are small and fed frequently, the feeding will not entail a high glucose increase and acute insulin response. It is also important to feed the horse at fixed times, since regular feeding times are positive for feed conversion (Pięta 2004; Sarnowski 2005; Samsel 2008).

The horse's ration should be properly supplemented with feed additives and minerals, of which selenium is one of the most important, due to its chronic deficiency observed in feeds across Poland. L-carnitine added to horse feed can contribute to increased fatty acid oxidation, which supplies energy necessary for the proper functioning of muscles (Janicki and Buzała 2011; Polasik et al. 2015 ). A dose of 100-200 $\mathrm{g} / \mathrm{kg}$ of this additive administered in the breeding season helps to improve the semen quality of stallions (Arruda et al. 2010). The content of minerals in the feed should not be fixed, it should be permanently monitored and adjusted depending on the feed quality, field conditions of crop production, harvesting and storage conditions, as well as feed processing method. Mineral concentration can vary significantly and not always sufficient to cover the needs of the horse. The most important are macronutrients, such as calcium, phosphorus, magnesium, sodium, chlorine and sulfur. Due to a high potassium content in feed plants, this element should not be included in mineral-vitamin feed supplements (Urbańczyk 2007). Most important micronutrients are copper, zinc, manganese, iron, cobalt and selenium. Specific microflora of the equine colon synthesize B-group vitamins for the benefit of the horse. However, fat-soluble vitamins ( $A, D, E$ and $K$ ) are scarce (Dobrowolski et al. 2009; Ali et al. 2013; Brzóska et al. 2015).

The aim of the study was to analyze the expertise and awareness of horse owners in Poland in terms of equine nutrition and prevention of gastrointestinal tract disorders, as well as to carry out an overview of applied feeds. The study was performed using self-constructed questionnaire survey carried out among breeders of horses housed in equestrian centers and livery stables. 


\section{MATERIAL AND METHODS}

The analysis was based on data collected using our own questionnaire, which consisted of 31 questions on the entire feeding system and gastrointestinal disorders prevention. The questionnaires were filled by 460 horse owners. For the analysis, we selected 361 questionnaires which did not contain errors. The answers were assigned to 4 groups (Table 3). The criteria were the number of horses and their way of use. In relation to herd size, the respondents were divided as owners of one or two horses, or owners of three or more horses. Next, these were divided according to the usage: recreational and sport horses.

Table 3. Distribution of surveyed groups

Tabela 3. Podział grup ankietowanych

\begin{tabular}{|c|c|c|c|}
\hline $\begin{array}{l}\text { Groups } \\
\text { Grupy }\end{array}$ & $\begin{array}{l}\text { Number of horses } \\
\text { Liczba koni }\end{array}$ & $\begin{array}{l}\text { Use type } \\
\text { Typ użytkowania }\end{array}$ & $\begin{array}{l}\text { Number of filled questionnaires } \\
\text { Liczba wypełnionych ankiet }\end{array}$ \\
\hline I group - grupa & $1-2$ & $\begin{array}{l}\text { sport } \\
\text { sport }\end{array}$ & 54 \\
\hline II group - grupa & $1-2$ & $\begin{array}{l}\text { recreation } \\
\text { rekreacja }\end{array}$ & 97 \\
\hline III group - grupa & $\begin{array}{l}3 \text { and more } \\
\text { i więcej }\end{array}$ & $\begin{array}{l}\text { sport } \\
\text { sport }\end{array}$ & 69 \\
\hline IV group - grupa & $\begin{array}{l}3 \text { and more } \\
\text { i więcej }\end{array}$ & $\begin{array}{l}\text { recreation } \\
\text { rekreacja }\end{array}$ & 141 \\
\hline $\begin{array}{l}\text { Total } \\
\text { Łącznie }\end{array}$ & - & - & 361 \\
\hline
\end{tabular}

Horse breeders and owners from all over the country took part in the survey. The largest numbers of respondents were from the Masovian and Lower Silesian Voivodeships. The horse breeds most commonly used in Poland for recreation are Malopolski, Wielkopolski, and Polish Half Bred.

\section{RESULTS}

While calculating feed rations for horses, the owners consider various factors. Basic knowledge on how to formulate a feed ration will decide about its quality and whether the ration satisfies the nutritional requirements of the horse or not.

All respondents find the amount of work the horse has to perform as the most important factor in feed ration formulation (approx. 22-23\% in all groups) and this is one of the key factors taken into account in livestock animals feeding management. Other factors include body weight and body condition (both at a level 15-19\% of responses). Feed conversion is also important, which often differs between animals and affects the condition. Subsequent criteria, representing $10-16 \%$ of responses, are behavior and age of the horse. Figure 1 shows that this factor is more important among recreational horses than in the group of sport horses. This is influenced by the level of riding skills of the people working with the horses. The age is correlated with the demand for particular nutrients and with the type of feed applied. Next, the owners take into account horse feeding recommendations and advice obtained from 
a veterinarian (6-8\% of respondents). More and more breeders are using nutritional recommendations, which provide adequate knowledge on how to prepare feeding rations. Veterinarians are also highly esteemed by horse breeders and owners, and their advice is highly appreciated. However, the expertise of a veterinarian on how to calculate daily rations for utility horses is usually lower compared to animal husbandry specialists who professionally deal with animal nutrition. Not more than 2 to $6 \%$ of respondents use the nutritional recommendations prepared by horse-feeding specialists. Those who do, primarily manage sport horses. Equine nutrition professionals possess both skills and expertise to appropriately calculate the ration. Breeders should more often use this knowledge in their horse feeding management. Only 1-3\% of respondents reach for professional magazines and popular-science literature. Recent achievements in related fields of science presented in this type of literature add new, valuable information to the knowledge of the horse caregiver. Figure 1 presents the frequency of selected responses.

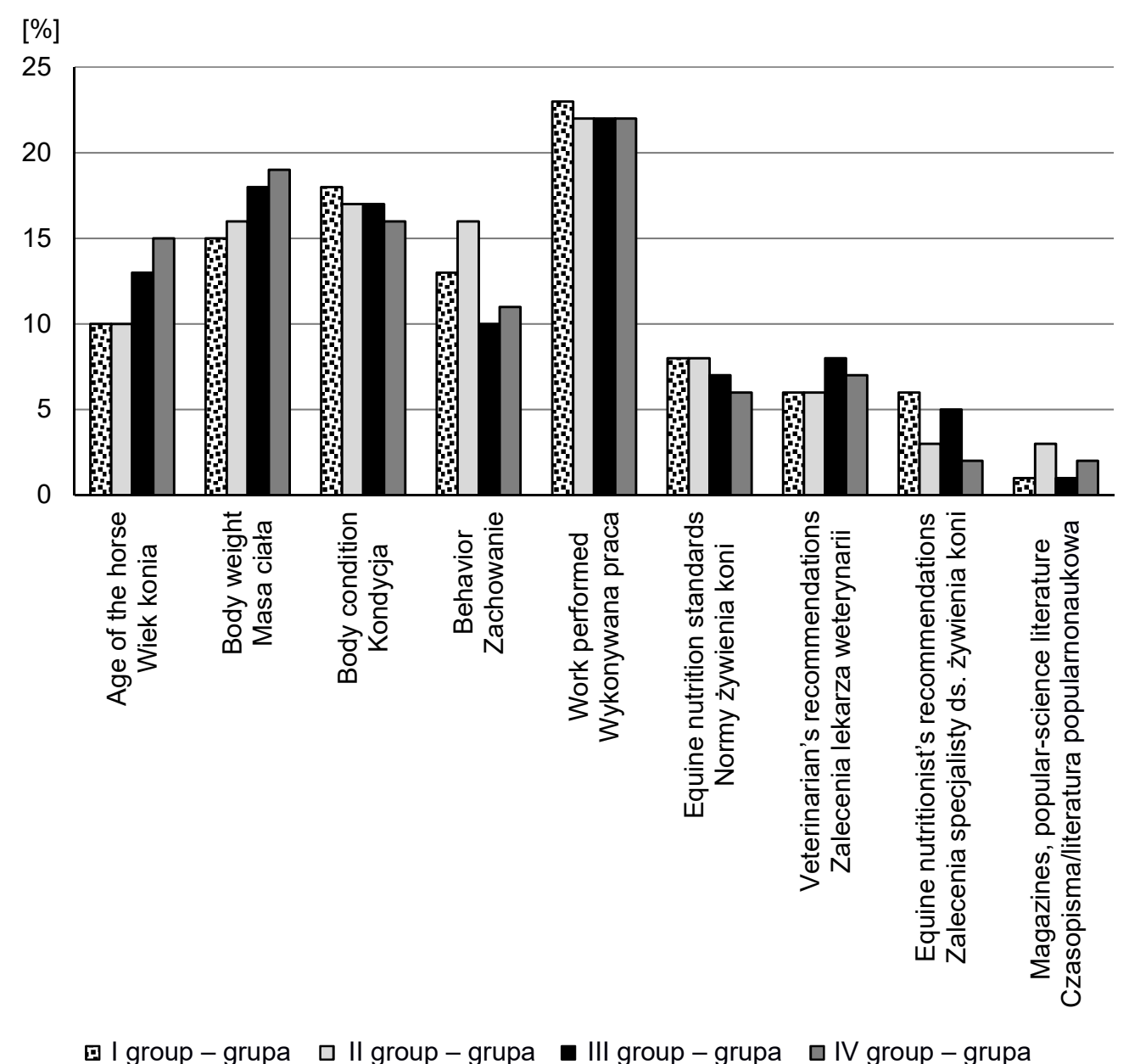

Fig. 1. Criteria according to which daily rations for horses are formulated Ryc. 1. Kryteria ustalania dziennej dawki pokarmowej dla koni

Oats are the most commonly fed grain among owners having one or two horses used for recreation ( $61 \%$ of respondents). The same percentage of owners use oats in groups I and IV $(57 \%)$. The least often, only $45 \%$ of owners, use oats as the basic grain in group III. This may 
be due to greater awareness of owners about nutrition and higher requirements in terms of carefully balanced diet in sport horses. Other grains used by the respondents were mostly barley, wheat bran, followed by corn, less often triticale and linseed, mainly in a processed form of oilcake. Other concentrate components mentioned by the respondents include primarily beet pulp, sunflower husks, post-extraction soybean meal and alfalfa chaff. Most often, the respondents described concentrate feed as a mix of oats, beet pulp and wheat bran. This mix has an improper calcium-to-phosphorus ratio, i.e. $1: 2.7$. The correct ratio here should be 1.5-2 : 1. Excess phosphorus reduces absorption of calcium in the body, leading to its removal from the bones, thereby making the bone flexible. To prevent this, roughage with a high content of calcium, such as alfalfa hay, should be fed.

Referring to the previously described principles of equine nutrition, it is important to divide the ration of concentrate feed into several smaller portions. More than $65 \%$ of the owners feed the horses three times a day, and recreation horses usually get feed twice a day, $51-55 \%$, and three times a day, 35\%. More frequent feeding of sport horses with concentrates may result from a higher proportion of such a fodder in the daily ration. Respondents who offer concentrates only once a day do not exceed $13 \%$ of the studied population and these are mainly recreational horse owners. All the owners of more than three sport horses apply the division of the daily ration to at least two portions (Fig. 2).

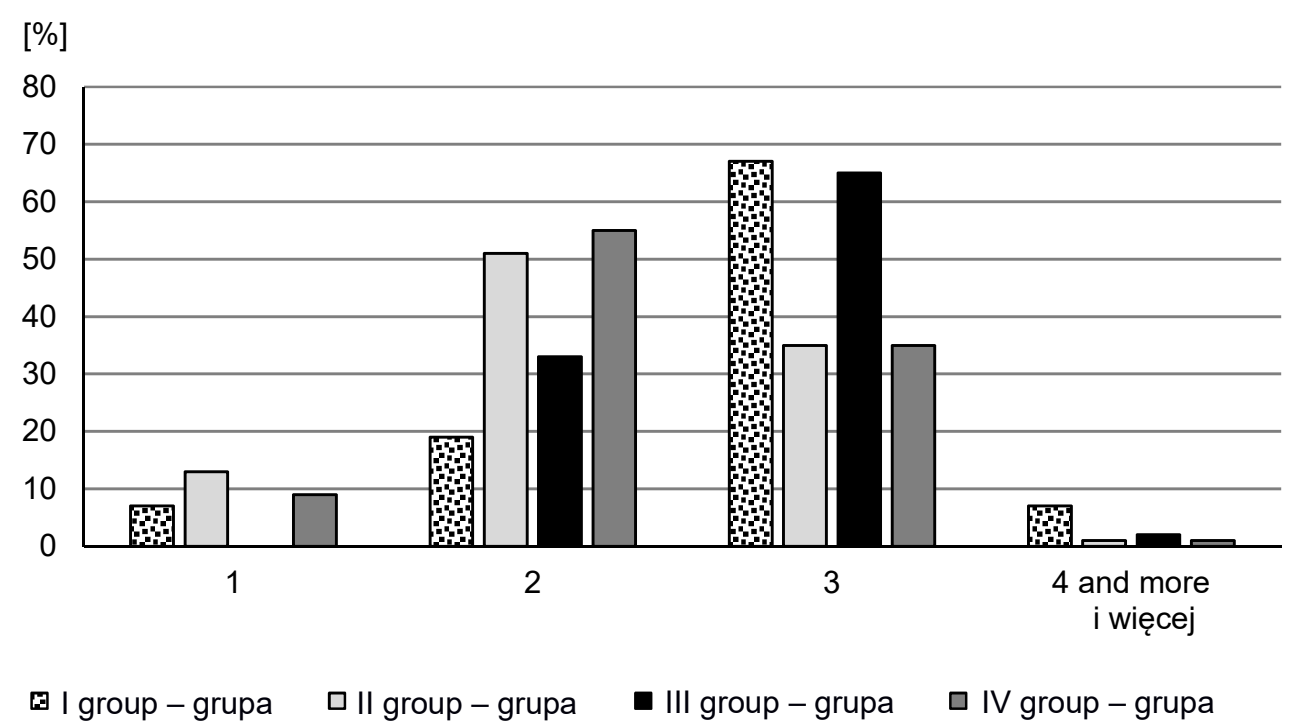

Fig. 2. Number of portions into which one day's concentrate feed ration is divided Ryc. 2. Liczba porcji, na które podzielona jest w ciągu doby dawka paszy treściwej

On days without exercise, the ration should be reduced, particularly in terms of energy content. Energy demand on non-working days is lower, which results in excess energy in the applied ration. It is deposited as abdominal or subcutaneous fat, and also may cause hyperactivity. This was confirmed by about $33 \%$ of the respondents from group II and IV. In group III, most owners (45\%) reduces the ration on off-work days, in group I, only $19 \%$ of respondents do it. It is reasonable to regularly use an addition of chaff to a portion of concentrate. The most commonly used are chopped straw or alfalfa chaff. First of all, chaff is used by the owners of sport horses, in about $40 \%$ in both groups. In the case of recreational horses, affirmative answers were at the level of only $26-27 \%$. 
Oilseeds are not very popular among the surveyed owners. Mostly used by sport-horse owners from group III (41\%), by about $30 \%$ of respondents in groups I and IV, and only by $20 \%$ of respondents in group II (Fig. 3).

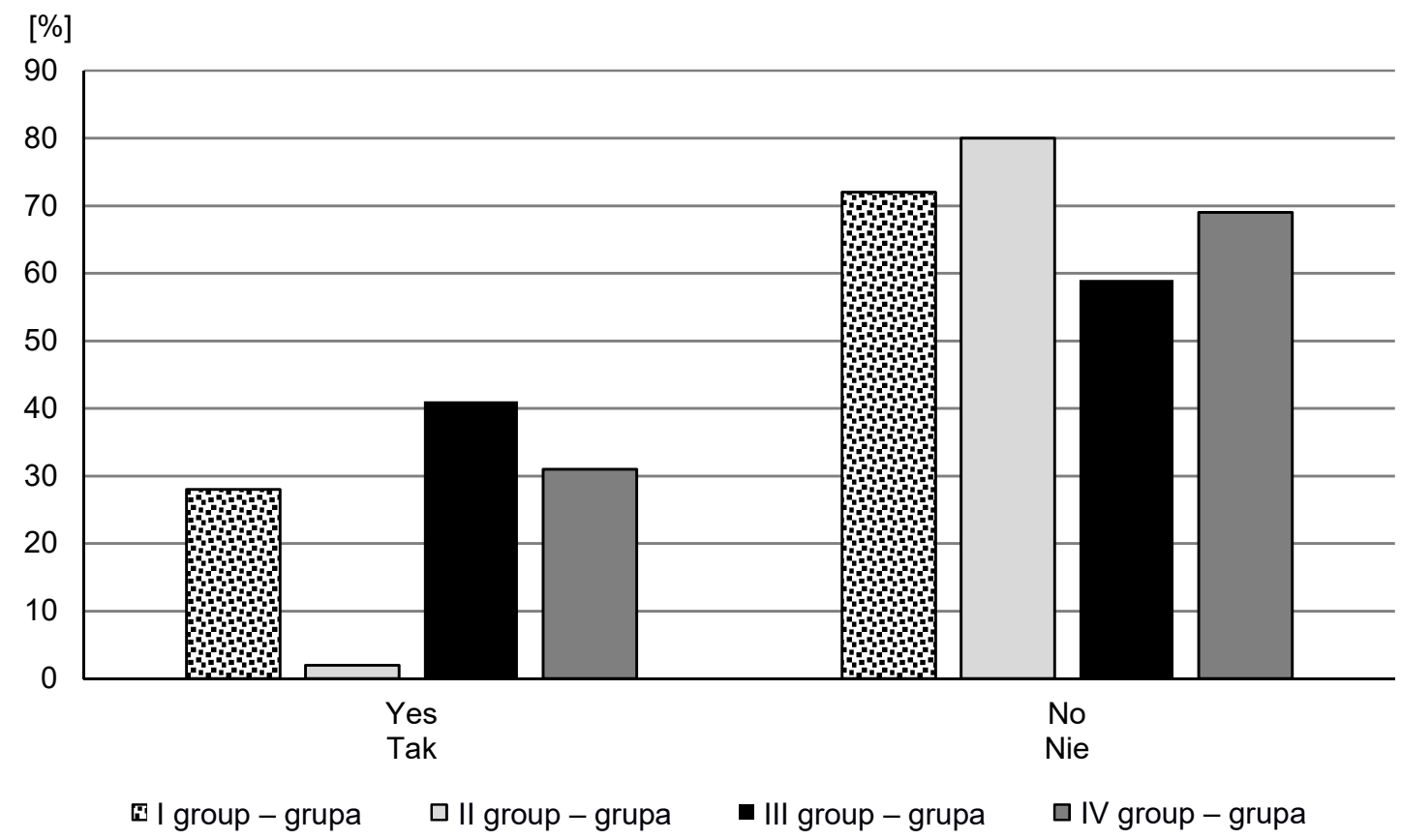

Fig. 3. Use of oil in feeding horses

Ryc. 3. Stosowanie oleju w żywieniu koni

Premixed feeds are most popular amongst sport-horse owners, $78 \%$ in group I and $83 \%$ in group III. In the remaining two groups, affirmative answers represent under $50 \%$ of respondents (44\% in group II and $48 \%$ in group IV). The choice of the premix depends on the composition, nutritional value and prise, to a lesser extent on a nutritionist's or feed producer's recommendations. Single respondents admit they value tips by colleagues-breeders.

The survey revealed that as many as 2 to $8 \%$ of horses has no regular access to an arena, $4-13 \%$ can run a few times a week. The structure of responses indicates that sport horses less often have the opportunity to move freely. This is due to risk of injuries which the valuable animals could sustain, since the paddock often serves them to discharge excess energy and release emotional strains. However, keeping the horses locked in their boxes leads to frustration and tensions, which may result in overloads and injuries. Such concerns are expressed also by $30 \%$ of group-I respondents, who let their horses run on paddocks only at good weather conditions. From 4 to $17 \%$ of respondents admit that their horses have no access to pasture. Permanent grasslands are a valuable and inexpensive source of nutrients for horses in the grazing season. Moreover, pasture gives the animals the opportunity to select and eat plants, e.g. herbs, supplementing possible nutritional deficiencies. Among the surveyed horse owners, $30-41 \%$ allow their horses to graze on pastures every day during the season. Although the off-season value of pasture is low, $20-39 \%$ of the studied horses have an all-year access to grasslands (Fig. 4). 


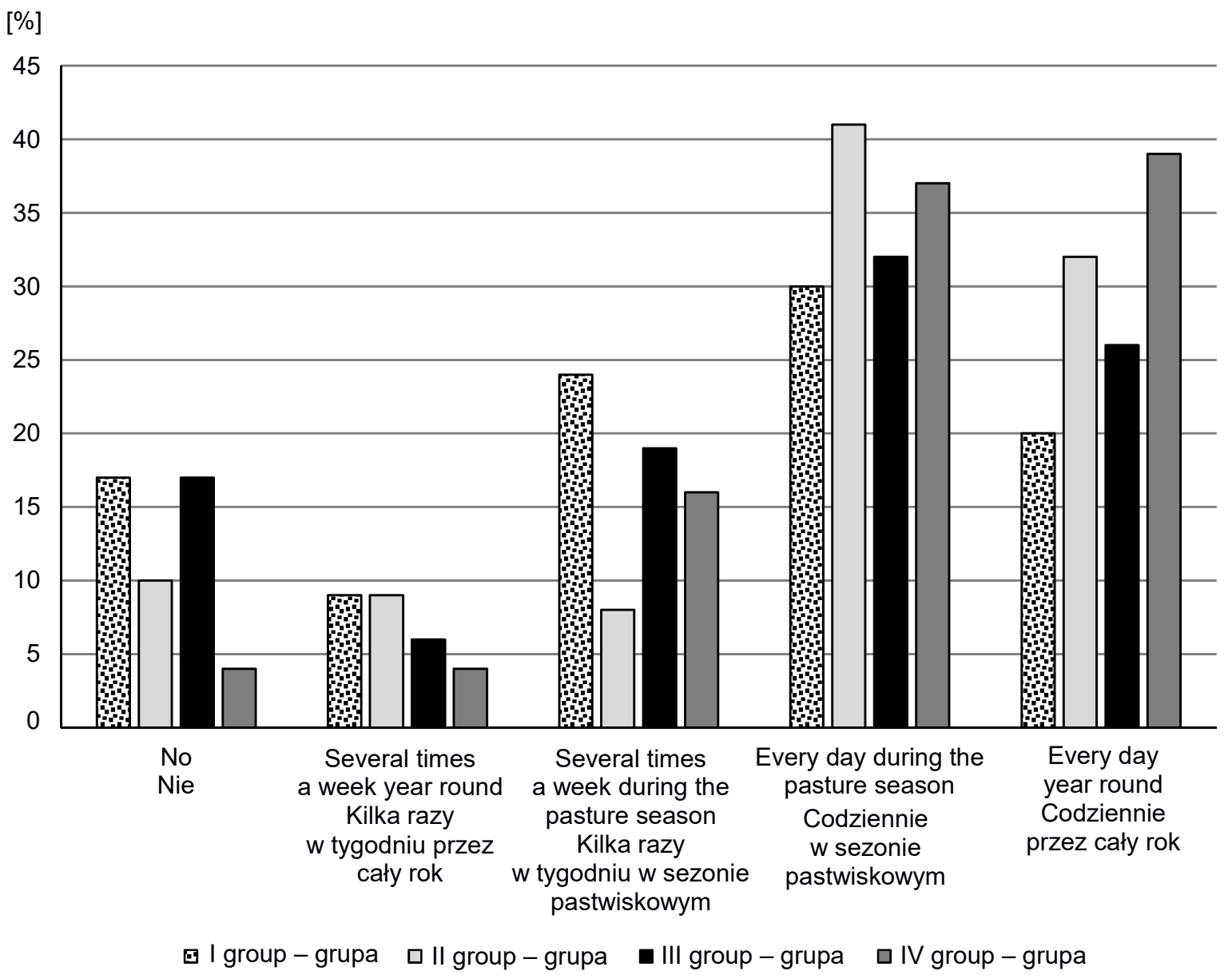

Fig. 4. Percentage breakdown of responses concerning the availability of pastures for horses Ryc. 4. Struktura procentowa odpowiedzi ankietowanych dotyczących dostępności pastwisk dla koni

Rotational grazing is the most efficient pasture management system in terms of plant composition and quality of the sward, as well as forage yield. The biggest advantage of rotational grazing is that it allows protection of precious herbal species, which may be eaten out or trampled by the horses' hooves. Rotational grazing also allow the unused paddocks to re-grow and recover, which includes pasture care operations: uneaten vegetation can be easily mowed off, manure droppings harrowed, and some fertilizing and reseeding applied. A reasonable solution is also to use the pasture for both rotational grazing and mowing; in this system, the number of paddocks should be doubled. In all the surveyed groups, responses confirming pasture use in the rotational system represent around $50 \%$. On other pastures, lack of division will gradually cause their deterioration.

During the period of intensive training, it is advisable to include in the diet vitamins and minerals, which will primarily replenish electrolytes. These components must be balanced with the ingredients taken by the horse with feed to avoid excess and associated negative effects on the body. Most of the respondents declaring the use of mineral-vitamin supplementation are the owners of sport horses, 39\% (group I) and 55\% (group II) of them used supplementation 
throughout the year. In recreational horses, only 34\% (group II) and 29\% (group IV) of respondents gave positive answers. As many as $26 \%$ of respondents from group II and $18 \%$ of group IV do not apply mineral-vitamin formulations. I the remaining two groups, these are 7 and $10 \%$ of respondents (Fig. 5).

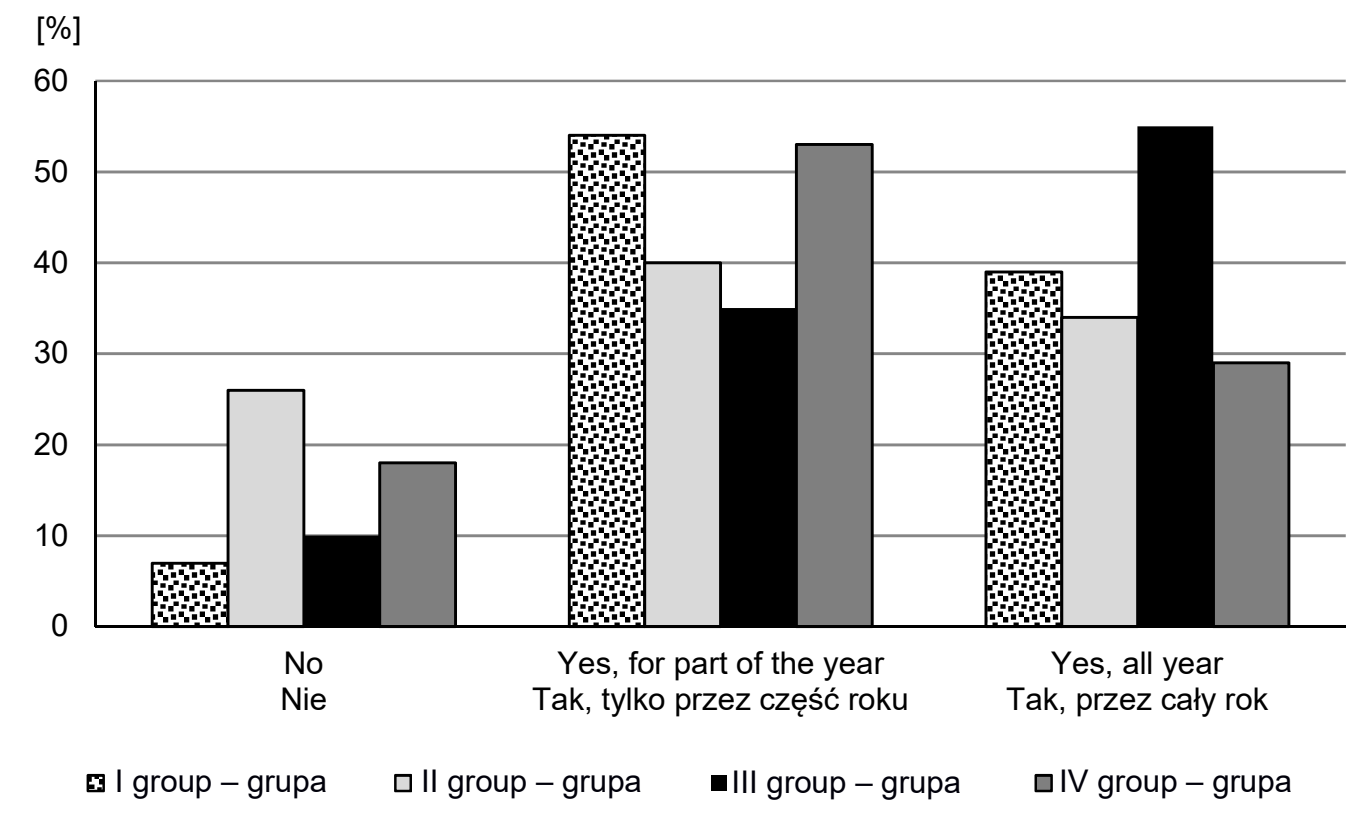

Fig. 5. Use of mineral and vitamin supplements in the diet

Ryc. 5. Stosowanie w żywieniu preparatów mineralno-witaminowych

Herbs have both their enthusiasts and skeptics. The latter raise the problem of inability to accurately determine the content of active substances in herbs. Undoubtedly, they are often an excellent replacement for antibiotics or other medications. Herbs are widely used in organic livestock farming. Herbs and herbal products are not used by 23 to $32 \%$ of respondents, $18-33 \%$ use them only to treat diseases. $28-43 \%$ of respondents use them "sometimes", and regular users of herbs represent 7 to $16 \%$ of respondents (Fig. 6).

Prebiotics and probiotics enhance the growth of gut microbiota. Rich intestinal microflora guarantees proper digestion and usage of nutrients contained in the feed. Moreover, gut microorganisms facilitate adjusting to changes in feeding and reduce the risk of health problems in the period of nutrition-related stress, e.g. in the beginning of the grazing season. Gut flora stabilizers are not very commonly used among the responding breeders. A many as $79 \%$ of group II owners do not use them at all, as well as $75 \%$ in group I, $71 \%$ in group IV and $58 \%$ in group III. During the nutrition-related stress period, gut flora stabilizers are used by $17 \%$ of respondents in groups III and IV, $15 \%$ in group I and only $7 \%$ in group II. Their application in some parts of the year is declared by $4 \%$ horse owners in groups I, II and III, and only $1 \%$ in group IV (Fig. 7 ). 


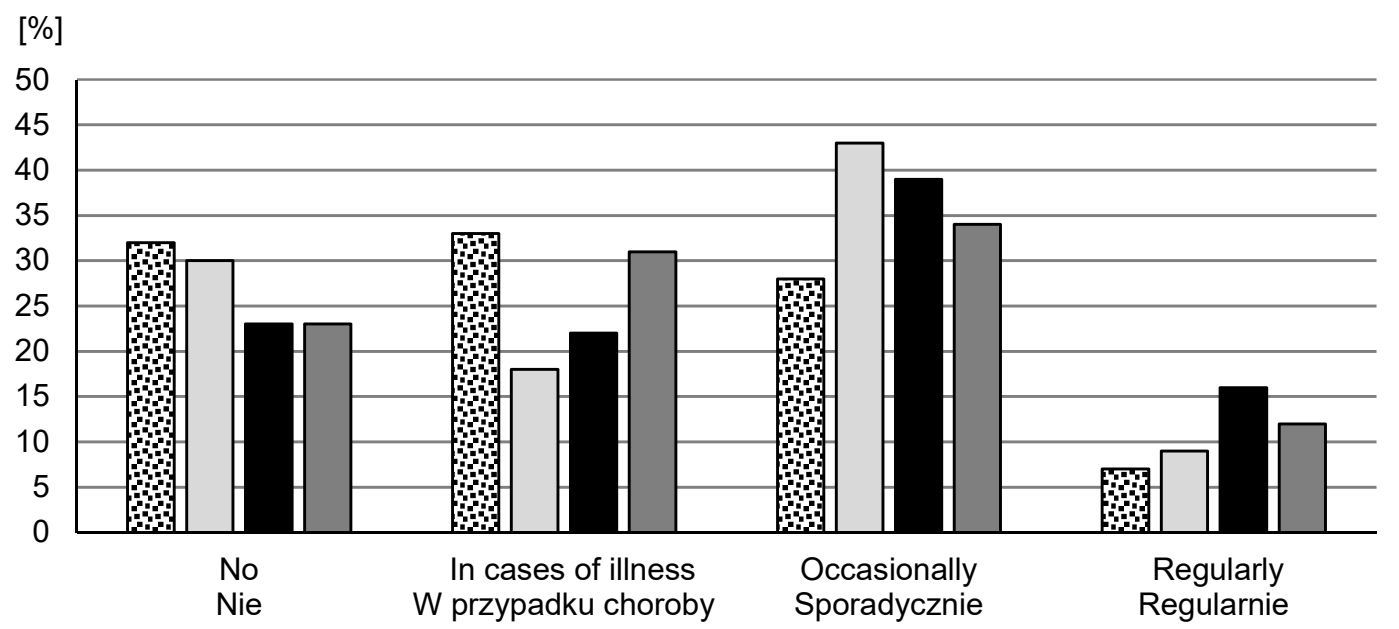

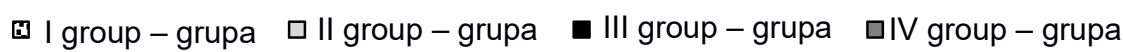

Fig. 6. Use of herbs or herbal preparations in the diet

Ryc. 6. Stosowanie ziół lub preparatów ziołowych w żywieniu

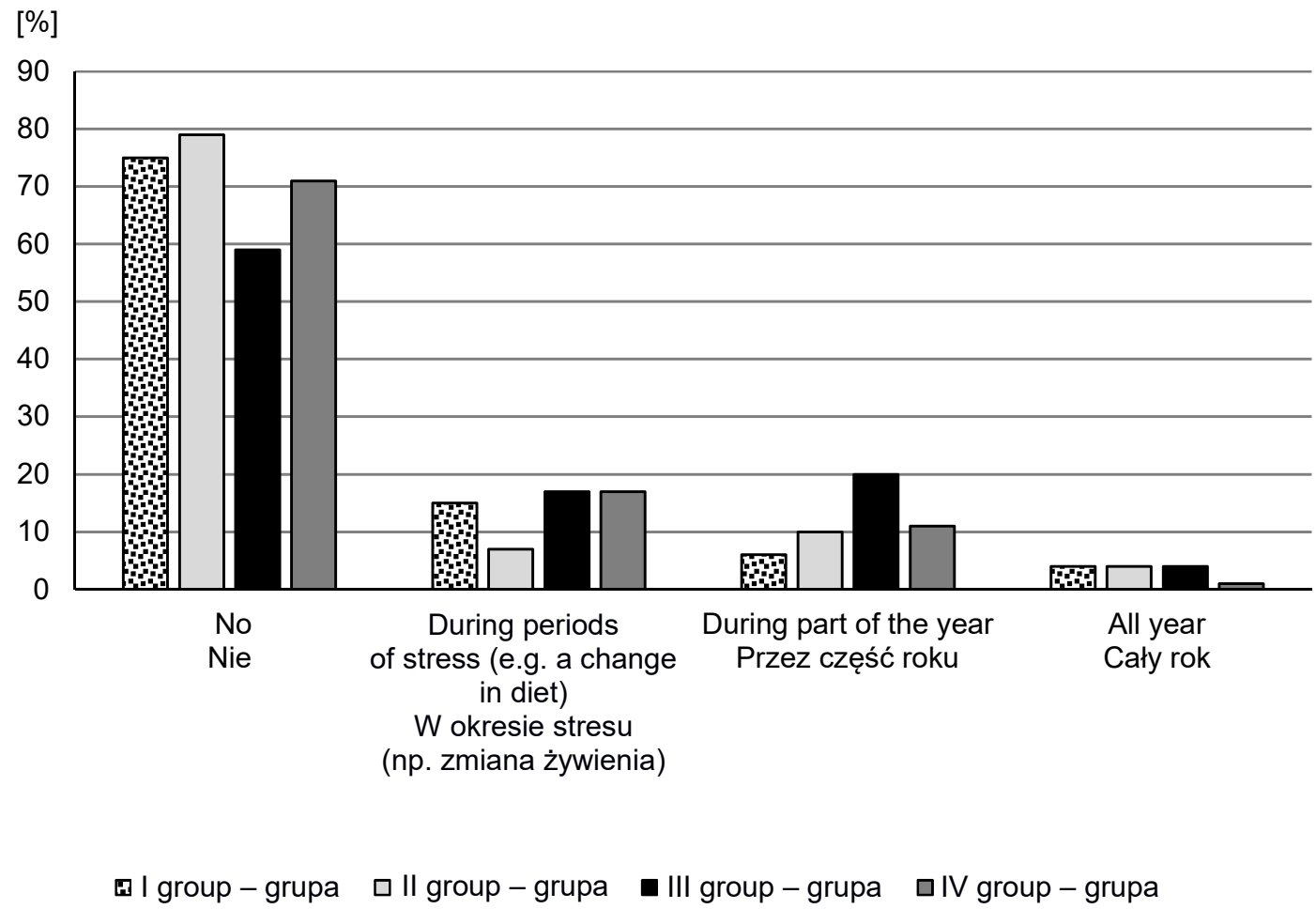

Fig. 7. Use of gut flora stabilizers

Ryc.7. Stosowanie stabilizatorów flory jelitowej

Taking the feed from the ground is natural to horses. It provides a physiological extension of the gastrointestinal tract. The higher mongers are placed, the more disturbed the natural position of the guts. Most respondents (70-75\%) place mongers at the height of horse's shoulder, 7 to $13 \%$ above that height. About $12 \%$ of horse owners in all groups place the feeder at the horse knee, 2 to $12 \%$ on the floor. 
Waterers should not be placed directly beside the feeders containing grain, so as to restrict drinking during concentrate feeding. The drinker and the manger are placed side by side in box stalls in $20 \%$ of facilities in groups III and IV, whereas in the remaining groups in $26-28 \%$. No drinker in the stall means that the horse lacks unlimited access to water. In the case of sport horses, these are 3 and $7 \%$, while in groups of recreational horses, 11 and $14 \%$.

The best way to provide forage is to use small-mesh net hay bags, hanging below the horse's shoulder. The bags ensure slow feeding and prevent boredom during hours spend in the box stall. The height below the shoulder ensures the appropriate gastrointestinal tract position. From 4 to $15 \%$ of horses in the survey are offered hay in so hung net bags, of which more are recreational horses. $4-10 \%$ of bags are hung above the shoulder. Most often, however, $68-83 \%$ of cases, hay lies directly on the floor, which is a good method, though the horses eat the forage much quicker than using the net bag.

Hay racks are usually mounted high, so the horse has to raise its head to feed and the gastrointestinal tract is in unnatural position. Among the respondents, 6 to $13 \%$ used hay racks in the stable. Hay racks are often found in old stable buildings.

A small number of people feeding horses every day ensures the comfort of regularity and quiet. Any changes in the feeding routine may result in anxiety, which affects feed intake and, in consequence, feed digestion processes. Ideally, the number of caregivers should be reduced to a minimum and each feeding operations should follow an established order, to which the animals can easily get used. Among the respondents, the most common option was "2-3 people throughout the year", selected by 44 to $64 \%$, followed by " 1 person throughout the year", selected by 22 to $48 \%$ respondents.

According to the survey, most horses are dewormed twice a year (58-70\%), which may not be sufficient to fight all parasites. From 24 to $39 \%$ of horses are dewormed three or more times a year, 3 to $6 \%$ once a year. No one selected the option "never" in relation to deworming.

If deworming is supposed to be efficient, the active ingredient of dewormer should be changed on a regular basis to prevent growing resistance of parasites. From 15 to $30 \%$ of respondents do not change the deworming ingredient, 9-33\% do not know whether they change the substance or not, being guided by other factors while choosing the formulation. These primarily follow the veterinarian's recommendations, scope of action and the price of the medication. Between 46 and $71 \%$ are aware to and do change the deworming medication on a regular basis.

As it was mentioned previously, the sharp enamel points of horses teeth should be regularly inspected and treated by filing if needed. Unfortunately, in $35 \%$ of recreational horses this treatment is never carried out. In sport horses, this number is $7-11 \%$. The frequency of teeth filing should be established by the veterinarian for each horse individually, since the rate of tooth wear varies between animals. It is a rare exception that a horse never needs this treatment. Neglected teeth may badly impede ingestion and chewing of the feed. The remaining answers show that many owners regularly care for their horses teeth.

\section{DISCUSSION}

There are a range of traditional methods in today's equestrianism and horse breeding. This also pertains to nutrition, which - without a doubt - is strongly influenced by tradition. According 
to Świstowska et al. (2006), only proper nutrition ensures that the potential stored in equine genes will be fully available.

Calculating daily rations for horses in training and in competition consists in composing balanced levels of nutrients - protein, carbohydrates and lipids - and digestible energy, which will cover the nutritional requirements of the horse without excessive load of the digestive system. As a rule, new feeds and new feeding systems are sought only when problems within the previous feeding arise, or when the previous feeding seems insufficient as the workload of intensively used horses increases.

Many breeders and owners are unable to distinguish between concentrate feeds and forages, which is reflected in the questionnaires. In a number of cases, respondents did not considered the green forage eaten by grazing horses on pasture as part of daily ration.

Many respondents admit they fed premixed feeds to their horses. However, in my opinion, the quantity declared for recreational horses is too high. There is an opinion, especially among the owners of recreation-riding horses having more than two animals, that premixed feeds or pellets are to expensive. It is true that pre-formulated for horses are usually more expensive than those similar intended for other livestock animals. The owners of small riding schools or small recreation stables cannot afford too high feeding costs. One might suspect also that some for respondents were unable to discern the difference between marked pre-formulated feeds from mixes formulated on-farm from ingredients purchased elsewhere.

According to Mirowski (2014), the concentrations of elements in the body of a horse depend on their content in the feed. If we look at selenium, its low level in the feed is a direct consequence of the fact that its soil content is very poor. It is a very important trace element for competition horses, hence the owners should take care of its proper supplementation. This also pertains to other micronutrients. Mirowski and Didkowska (2015) report that rations based on oats and hay are zinc-deficient, which the authors support with their own research. In such cases, zinc should also be supplemented in diet. Feeds are also deficient in many other micronutrients and vitamins. The owners are recommended to examine their horses for any nutrient deficiencies to know which nutrients are missing or deficient in the usual feed. It must be stressed that 7 to $26 \%$ of respondents do not use any mineral-vitamin supplements, and 35 to $54 \%$ apply such supplementation only in some part of the year. It is quite obvious that the shortage of various micronutrients may be common in animals of this group, particularly in the case of performance horses, whose demand for minerals and vitamins is high.

Most respondents deworm their horses twice a year (58-70\%). Jagło et al. (2010) claim that a double deworming treatment allows elimination of hypodermosis and taeniasis. Severe cases of strongylid infections, however, will need more than two deworming treatments. Since most respondents, $58-70 \%$, deworm the horses twice a year, and $4-6 \%$ only once, this may not be sufficient to eliminate all parasitic threats and diseases in the herd. Also the formulations should be changed on a regular basis, in order to avoid increasing resistance of the parasites.

It must be kept in mind that nutrition is a key part of equine care and management, and the caregivers need to be aware of the fact that improper nutrition can harm the horse. Should one be uncertain about what type of feed should be offered and what daily ration the horse requires, a veterinarian or an animal-nutrition specialist should be consulted in any case. 


\section{CONCLUSION}

A great number of horse breeders and owners have a low level of expertise in the field of feed science. They seldom consult equine nutritionists, as their recommendations are second least often considered factor in terms of daily ration formulating for horses. The rules of equine nutrition in terms of gastrointestinal tract disease prevention are often ignored by many owners of horses. This, however, may also be a result of lack of knowledge in this area, including the consequences of different procedures. Sport horses use arenas and pastures less frequently compared to recreational horses. It should be noted that nutrition of performance horses is the most demanding task, since we have to appropriately estimate the horse's current energy requirements, taking into account the condition and exercise effort the horse has to perform. The owners must realize how important element of equine care and management is its proper nutrition.

\section{REFERENCES}

Ali F., Lodhi L.A., Qureshi Z.I., Ahmad I., Hussain R. 2013. Serum mineral profile in various reproductive phases of mares. Pak. Vet. J. 33, 296-299.

Arruda R.P., Silva D.F., Alonso M.A., Andrade A.F. C., Nascimento J., Gallego A.M., Martins S.M.M.K., Granato T.M. 2010. Nutraceuticals in reproduction of bulls and stallions. R. Bras. Zootech. 39, 393-400.

Blendinger W. 1980. Psychologie und Verhaltensweisen des Pferdes. Berlin, Paul Parey Verlag, 28-80.

Brzóska F., Strzetelski J.A., Borowiec F., Jamroz D. 2015. Zalecenia żywieniowe dla koni i tabele wartości pokarmowej pasz. Kraków, Fundacja Inst. Zootech. BIB, 22-27, 5-59. [in Polish]

Chachułowa J. 2001. Żywienie koni, in: Żywienie zwierząt i paszoznawstwo. Podstawy szczegółowego żywienia zwierząt. Red. D. Jamroz, A. Potkański. Tom 2. Warszawa, Wydaw. Nauk. PWN. [in Polish]

Dobrowolski M., Jodkowska E., Marycz K., Lisowska K. 2009. Wpływ żywienia na zawartość wapnia i fosforu w sierści i włosach roczniaków pełnej krwi angielskiej [Effect of nutrition on the content of calcium and phosphorus in hair of English thoroughbred yearlings]. Zesz. Nauk. Uniw. Przyrod. Wroc., Biologia i Hodowla Zwierząt 59(575), 77-86. [in Polish]

Jagła E., Popiołek M., Knecht D., Łuczyński T., Jarnecki H. 2010. Wpływ systemu utrzymania oraz fenologii na inwazje słupkowców u koni z wybranych stajni województwa opolskiego i Wrocławia [Effect of breeding conditions and phenology on the invasions of strongylid nematodes in horses from selected stables in Opolskie Province and Wrocław]. Zesz. Nauk. Uniw. Przyrod. Wroc., Biologia i Hodowla Zwierząt 60(577), 181-194. [in Polish]

Janicki B., Buzała M. 2011. L-karnityna w żywieniu koni sportowych [L-carnitine in sport horses nutrition]. Med. Weter. 67(12), 824-828. [in Polish]

Kowalska A. 2008a. Rola tłuszczów w diecie koni [The role of fats in the equine diet]. Hod. Jeździec 1 , 58-60. [in Polish]

Kowalska A. 2008b. Białko w żywieniu koni wyczynowych [Protein in performance horse nutrition]. Hod. Jeździec 2, 54-56. [in Polish]

Meyer H., Coenen M. 2009. Żywienie koni. Warszawa, PWRiL, 34-275. [in Polish]

Mirowski A. 2014. Selen w żywieniu koni. Cz. I. Problematyka niedoboru selenu [Selenium in equine nutrition. Part I. Issues of selenium deficiency]. Życie Weter. 89(7), 581-582. [in Polish]

Mirowski A., Didkowska A. 2015. Cynk w żywieniu koni [Zinc in equine nutrition]. Życie Weter. 90(2), 101-102. [in Polish]

National Research Council. 2007. Nutrient requirements of horses, 6th rev. ed. Washington, The National Academies Press. 
Pięta A. 2004. Praktyka w żywieniu koni sportowych [Practical sport horses nutrition]. Hod. Jeździec 4, 49-53. [in Polish]

Pięta A. 2009. 12 miesięcy w żywieniu koni [The four seasons in equine nutrition]. Świat Koni 2, 8-13. [in Polish]

Pilliner S. 2008. Praktyczne żywienie koni i kuców. Warszawa, SIMA WLW. [in Polish]

Polasik D., Pikuła R., Gawlik J., Ochman J., Terman A. 2015. Analysis of the myostatin gene (MSTN) polymorphism in four breeds of horses. Folia Pomer. Univ. Technol. Stetin., Agric., Aliment., Pisc., Zootech. 320(35)3, 81-86.

Samsel J. 2008. Okiem weterynarza - kolki [Vet's advice - colic]. Hod. Jeździec 2, 58-59. [in Polish]

Sarnowski A. 2005. Racjonalne żywienie [Rational nutrition]. Hod. Jeździec 1, 56-57. [in Polish]

Szarska E. 2003. Znaczenie badań diagnostycznych krwi w ocenie stanu zdrowia oraz efektywności treningu koni wyścigowych i sportowych [Importance of blood tests in the appraisal of the health status and training efficiency of racing and other sport horses]. Zesz. Nauk. AR Wroc., Rozprawy 203(471), 115. [in Polish]

Urbańczyk A. 2007. Bilans wapnia i fosforu [Calcium and phosphorus balance]. Świat Koni 5, 46-48. [in Polish]

Abstract. The aim of the study was to study the expertise and awareness of Polish horse owners in terms of equine nutrition and prevention of gastrointestinal tract problems, as well as to overview the applied feeds. Knowledge on the structure and functioning of equine digestive system and digestion processes is essential if we want to plan good nutrition schemes, especially for sport horses. Having a profound knowledge on horse feeding and nutrition, the owner may avoid many problems with the horse's fitness and reduce the risk of digestive disorders. Horses are animals that basically feed on pasture. However, the work they perform for humans, which is associated with intense physical activity, requires additional energy and nutrients. Most difficult is the nutrition of performance horses, which requires proper determination of energy needs at the given level of training load, as well as adequate mineral-vitamin supplementation that will meet the needs of the horse. The entire consistent nutrition system should be treated with utmost care and consideration, since it is the key factor influencing the health status of the horse. 